\title{
Evaluation of clinical, laboratory, and electrophoretic profiles for diagnosis of malnutrition in hospitalized dogs
}

\section{Avaliação clínica, laboratorial e perfil eletroforético como auxílio diagnóstico de desnutrição em cães hospitalizados}

\author{
Andrei Kelliton Fabretti ${ }^{1 *}$; Inês Cristina de Batista Fonseca ${ }^{2}$; \\ Alexandre Freitas Coelho ${ }^{3}$; Cristiane Nakahata Silva ${ }^{3}$; Patrícia Mendes Pereira ${ }^{1}$
}

\begin{abstract}
Malnutrition is a major factor associated with increased rates of mortality and readmission, longer hospital stays, and greater health care spending. Recognizing malnourished or at-risk animals allows for nutritional intervention and improved prognosis. This study evaluated the association between clinical, laboratory, and electrophoretic variables and the nutritional status (NS) of hospitalized dogs in order to generate a profile of the sick dog and to facilitate the diagnosis of malnutrition. We divided 215 dogs into groups according to the severity of the underlying disease and we determined the clinical NS based on the assessment of the body condition score and the muscle mass score. The NS was classified as clinically well nourished, clinical moderate malnutrition, or clinical severe malnutrition. Statistical analyses were conducted by using the chi-square test or Fisher's exact test; the Kruskal-Wallis test was used for continuous variables. A strong association was found between malnutrition and the severity of the underlying disease. In hospitalized dogs, low body mass index values, anemia, low hemoglobin concentrations, high fibrinogen concentrations, decreased albumin fraction, and increased gammaglobulin fraction (in electrophoresis) were associated with malnutrition, reinforcing the classification of poor NS. However, the skin and coat characteristics, the total number of lymphocytes, blood glucose, cholesterol, and total protein concentration were not found to be good predictors of NS.
\end{abstract}

Key words: Critical patients, nutritional status, undernutrition

\section{Resumo}

A desnutrição é um dos principais fatores relacionados ao aumento das taxas de morbimortalidade, de reinternação, maior tempo de hospitalização e gastos com cuidados na saúde. Reconhecer o animal desnutrido ou em risco permite a intervenção nutricional e melhora do prognóstico. O presente trabalho avaliou a relação dos resultados clínicos, laboratoriais e eletroforéticos com o estado nutricional (EN) de cães hospitalizados, de maneira a traçar o perfil do cão enfermo, facilitando o diagnóstico de desnutrição. Foram estudados 215 cães, divididos de acordo com a gravidade da doença de base e com o EN clínico, através da avaliação do escore de condição corporal e do escore de massa muscular. O EN foi classificado como clinicamente bem nutrido, desnutrição clínica moderada e desnutrição clínica severa. A análise estatística foi baseada no teste Qui-quadrado ou teste exato de Fisher. No caso de variáveis contínuas, o teste utilizado foi o de Kruskal-Wallis. Houve forte associação entre desnutrição e gravidade da doença de base. Foi observado em cães hospitalizados, que os baixos valores de índice

\footnotetext{
Profs., Dept ${ }^{\circ}$ de Clínicas Veterinárias, Universidade Estadual de Londrina, UEL, Londrina, PR, Brasil. E-mail: fabretti@uel.br; pmendes@uel.br

2 Prof ${ }^{a}$, Dept $^{\circ}$ de Agronomia, UEL, Londrina, PR, Brasil. E-mail: inescbf@uel.br

3 Discentes do Curso de Graduação em Medicina Veterinária, UEL, Londrina, PR, Brasil. E-mail: cristianenakahata@hotmail. com; alexandrefcoelho@hotmail.com

* Author for correspondence
} 
de massa corporal, anemia, baixas concentrações de hemoglobina, altas concentrações de fibrinogênio, diminuição da fração albumina e aumento da fração gamaglobulina (na eletroforese) estão associados com desnutrição, reforçando a classificação de um EN ruim. Entretanto, as características de pele e pelagem, o número total de linfócitos, a glicemia, colesterol e a concentração de proteína total não foram considerados bons indicadores do EN.

Palavras-chave: Paciente crítico, estado nutricional, subnutrição

\section{Introduction}

Interest in the assessment of nutritional status (NS) has increased with the recognition of the high incidence of malnutrition among hospitalized patients. NS often worsens with hospitalization, particularly in dogs and cats with critical illnesses (REILLY et al., 1995; BRUNETTO, 2006; MAULDIN; DAVIDSON, 2007; BRUNETTO, 2010).

Malnutrition is a condition in which the supply of nutrients and energy is insufficient to meet the demand of the organism (SHIMIZU; RABELO, 2005). This situation is detrimental to metabolism and evolves to changes in body composition, such as a reduction in fat and muscle mass, weight loss, and poor appearance of the skin and coat (VANNUCCHI; UNAMUNO; MARCHINI, 1996; JEEJEEBHOY, 2000; MEIJERS et al., 2010).

Up to $50 \%$ of hospitalized animals are believed to be malnourished (CHANDLER; GRECO; FETTMAN, 1992). A precarious NS is directly or indirectly related to a higher rate of hospital infections, increased time and cost of hospitalization, higher rates of complications and readmissions, and increased mortality (REILLY et al., 1995; VANNUCCHI; UNAMUNO; MARCHINI, 1996; REMILLARD; ROUDEBUSH，2000; LOGAN; HILDEBRANDT, 2003). Therefore, recognition of the malnourished or at-risk animal enables identification of which patients require intervention, thereby resulting in an improved response to treatment and prognosis (SPEROTTO; SPINELLI, 2010).

However, the classification of patients as wellnourished or malnourished remains subjective because no clear definition of the cut-off limits for characterizing NS exists (VANNUCCHI; UNAMUNO; MARCHINI, 1996; ACOSTA; GOMEZ-TELLO; SANTANA, 2005; MEIJERS et al., 2010). In addition, routine laboratory tests and many clinical signs suggestive of malnutrition are considered to lack sensitivity and specificity for this purpose (REILLY et al., 1995; GAUDELUS et al., 2000). Therefore, hospitalized dogs are often diagnosed with malnutrition at a late stage, and NS monitoring is infrequent and inadequate (CHANDLER; GUNN-MOORE, 2004).

In order to increase confidence in the assessment of NS, the joint use of several parameters is recommended to overcome the limitations of each feature in isolation (FOUQUE et al., 2008). In this context, this study aimed to evaluate the association of clinical, laboratory and electrophoretic variables with NS in hospitalized dogs in order to identify the NS of sick dogs and to determine the occurrence of malnutrition.

\section{Material and Methods}

The study was conducted with dogs admitted to the Medical Clinic of Companion Animals, at the Veterinary Hospital of the Universidade Estadual de Londrina (HV-UEL). We evaluated 215 animals, of which $41.38 \%(89 / 215)$ were males and $58.62 \%$ (126/215) were females. The ages of the dogs ranged from 1 month to 17 years (median, 9 years) and the weight ranged from 2 to $55.4 \mathrm{~kg}$ (median, $8.3 \mathrm{~kg}$ ). The breeds were as follows: Poodle (15), Boxer (8), Cocker Spaniel (8), Shitzu (8), Dachshund (7), Lhasa Apso (5), Pitbull (5), Labrador Retriever (5), Pinscher (5), Dalmatian (4), Rottweiler (3), 
Basset Hound (2), Belgian Shepherd (2), Maltese (2), Schnauzer (2), and 1 each of Scottish Terrier, German Shepherd, West Highland White Terrier, Yorkshire, Chow-Chow, Golden Retriever, and Akita; further, 127 dogs were mongrels.

Animals with confirmed and suspected diagnoses were grouped as follows: gastroenteric (70), urinary system (48), infectious (42), neurological (25), hemolymph (16), respiratory system (10), oncological (9), reproductive (7), endocrine (4), skin (4), heart failure (4), immune-mediated (3), skeletal (3), and ophthalmic (1).

Laboratory tests were performed at the Laboratory of Clinical Pathology of the same institution. The Ethics Committee on Animal Use of UEL approved all procedures in this study (CEUA Case No. 31\11).

All dogs admitted to the clinic from August 2011 to August 2012 were considered for evaluation.
Animals with clinical dehydration above 7\% (BATEMAN; CHEW, 2006), aggressive animals, dyspneic animals, or those weighing less than 1.5 $\mathrm{kg}$ were excluded from the protocol.

The animals were divided into 3 experimental groups. Group 1 (G1), which was the control group $(n=29)$, was composed of dogs that were scheduled for elective castration and were categorized with a disease score of 1 according to the classification of the American Society of Anesthesiologists (ASA; 1984) described by Muir (2007) (Table 1); the nutritional assessment was made before surgery. Group 2 (G2) consisted of animals with mild to moderate disease severity $(n=154)$, classified with disease scores of 2 and 3. Group 3 (G3) consisted of animals with severe disease $(n=32)$, classified with disease scores of 4 and 5. Groups G2 and G3 were composed of hospitalized dogs; the nutritional assessment was performed within 48 hours after admission.

Table 1. Severity score of the animals' underlying disease.

\begin{tabular}{cl}
\hline Score & \multicolumn{1}{c}{ Condition } \\
\hline $\mathbf{1}$ & Normal patient without systemic disease; may have localized disease \\
$\mathbf{2}$ & Patient with moderate systemic disease \\
$\mathbf{3}$ & Patient with severe systemic disease; limiting, but not disabling \\
$\mathbf{4}$ & Patient with severe systemic disease that is a constant threat to life \\
$\mathbf{5}$ & Moribund patient who is not expected to survive more than 24 h with or without treatment \\
\hline
\end{tabular}

Source: American Society of Anesthesiologists (ASA; 1984) classification.

Table 2. Association between nutritional status and disease score, in frequency (\%), for dogs treated at the Veterinary Hospital of the Universidade Estadual de Londrina, from August 2011 to August 2012. Londrina, 2013.

\begin{tabular}{ccccc}
\hline Disease Score & $\begin{array}{c}\text { Severe Clinical } \\
\text { Malnutrition } \\
\mathrm{n}=64\end{array}$ & $\begin{array}{c}\text { Moderate Clinical } \\
\text { Malnutrition } \\
\mathrm{n}=53\end{array}$ & $\begin{array}{c}\text { Clinically Well } \\
\text { Nourished } \\
\mathrm{n}=98\end{array}$ & Analysis \\
\hline $\mathrm{G} 1, \mathrm{n}=29$ & $2(6.90 \%)$ & $4(13.80 \%)$ & $23(79.30 \%)$ & $\chi^{2}=21.04 * \mathrm{DF}$ \\
$\mathrm{G} 2, \mathrm{n}=154$ & $46(29.87 \%)$ & $42(27.27 \%)$ & $66(42.85 \%)$ & $=4$ \\
$\mathrm{G} 3, \mathrm{n}=32$ & $16(50.00 \%)$ & $7(21.87 \%)$ & $9(28.12 \%)$ & $\mathbf{p}<\mathbf{0 . 0 0 1}$ \\
\hline
\end{tabular}

$* \chi 2=$ Chi-square test, $\mathrm{DF}=$ degrees of freedom.

Source: Elaboration of the authors. 
Table 3. Association between nutritional status and body mass index (BMI), in mean and median (Q3-Q1), for dogs treated at the Veterinary Hospital of the Universidade Estadual de Londrina, from August 2011 to August 2012. Londrina, 2013.

\begin{tabular}{|c|c|c|c|c|}
\hline Variable & $\begin{array}{c}\begin{array}{c}\text { Severe Clinical } \\
\text { Malnutrition }\end{array} \\
\mathrm{G} 2, \mathrm{n}=64 ; \mathrm{G} 3, \mathrm{n}=16\end{array}$ & $\begin{array}{c}\text { Moderate Clinical } \\
\text { Malnutrition } \\
\mathrm{G} 2, \mathrm{n}=53 ; \mathrm{G} 3, \mathrm{n}=7\end{array}$ & $\begin{array}{c}\text { Clinically Well } \\
\text { Nourished } \\
\mathrm{G} 2, \mathrm{n}=98 ; \mathrm{G} 3, \mathrm{n}=9\end{array}$ & Analysis \\
\hline \multicolumn{5}{|c|}{ BMI $\left(\mathrm{kg} / \mathrm{m}^{2}\right)(\mathbf{G 1})^{1}$} \\
\hline Mean $\pm \mathrm{SD}$ & $14.78 \pm 3.64$ & $12.64 \pm 3.45$ & $14.34 \pm 4.06$ & \\
\hline Median & $14.57(16.54-12.28)$ & $12.33(14.40-10.10)$ & $14.60(16.30-12.12)$ & \\
\hline BMI $\left(\mathrm{kg} / \mathrm{m}^{2}\right)$ & & & & \multirow{3}{*}{$\begin{array}{c}\mathrm{K}-\mathrm{W} * \\
\chi 2=15.98 \\
\mathrm{DF}=2 \\
\mathbf{p}<\mathbf{0 . 0 0 1}\end{array}$} \\
\hline Mean \pm SD & $11.92 \pm 3.40$ & $12.64 \pm 3.45$ & $14.34 \pm 4.06$ & \\
\hline Median & $11.52(14.50-9.96)$ & $12.33(14.40-10.10)$ & $14.60(16.30-12.12)$ & \\
\hline BMI $\left(\mathrm{kg} / \mathrm{m}^{2}\right)$ & & & & \multirow{3}{*}{$\begin{array}{c}\mathrm{K}-\mathrm{W} \\
\chi 2=4.20 \\
\mathrm{DF}=2 \\
\mathrm{p}=0.129\end{array}$} \\
\hline Mean \pm SD & $19.10 \pm 19.16$ & $13.75 \pm 13.58$ & $17.91 \pm 5.25$ & \\
\hline Median & $11.56(14.30-9.90)$ & $13.70(14.74-11.30)$ & $16.04(21.70-13.43)$ & \\
\hline
\end{tabular}

${ }^{1}$ Reference Values: $11.8-15 \mathrm{~kg} / \mathrm{m}^{2}$ (MULLER; PINHEIRO; MENDONÇA, 2008).

$* \mathrm{~K}-\mathrm{W}=$ Kruskal-Wallis test, $\chi^{2}=$ chi-square test, $\mathrm{DF}=$ degrees of freedom.

Source: Elaboration of the authors.

Information from the body condition score (BCS) and muscle mass score (MMS) were used to determine the clinical NS. The 9-point Laflamme scale (1997) was used for the BCS classification. The MMS was classified according to the technique described by Michel et al. (2009).

Based on this information, the G1, G2, and G3 groups were subdivided into 3 groups: the clinically well-nourished group (CWN), composed of animals with $\mathrm{BCS}>3$ and $\mathrm{MMS}=3(\mathrm{n}=98)$; the moderate clinical malnutrition group (MCM), consisting of animals with $\mathrm{BCS}=3$ and/or MMS $=2(\mathrm{n}=53)$; and the severe clinical malnutrition group (SCM), composed of patients with BCS $<3$ and/or MMS $<$ $2(n=64)$.

The other clinical variables studied included the body mass index (BMI) and the physical characteristics of the skin and coat. We used the standard formula to calculate the BMI: weight $(\mathrm{kg}) /$ [height $(\mathrm{m})]^{2}$. The weight was measured by using an electronic scale, model LD $200 *$ (Manufacturer Lucastec Balança Eletrônica Ltda). The dogs were measured for height and were classified according to the technique described by Muller, Pinheiro, and Mendonça (2008).

The skin was evaluated for the presence of flaking, which was classified as absent, mild, moderate, or severe. The appearance of the coat was classified as opaque, oily, or shiny. Coat uniformity was evaluated by inspection and was classified as uniform hairy coverage or localized or diffuse, discrete, moderate, or severe alopecia. The coat texture was evaluated by palpation and by friction of the hairs, and was classified as hard or soft.

The design of the clinical study was conceived before execution of the project, and the evaluators were blinded to the results of the laboratory tests and the experimental group of the studied dogs. The studied animals were allocated into groups after data collection.

Laboratory tests were conducted after a single collection of blood $(5 \mathrm{~mL})$ from the jugular vein. The Mindray ${ }^{\circledR}$ BC-2800Vet apparatus was used to determine the total erythrocyte and leukocyte counts. The differential leukocyte count was determined by optical microscopy analysis of a 
blood smear stained by the Quick Panoptic stain for hematology. Plasma measurements were performed on a Siemens Dimensions RXL®, and the fibrinogen concentration was determined by using the heatprecipitation method (KANEKO; SMITH, 1967).

To perform serum electrophoresis, the samples were applied to an agarose gel (Celmgel®) that was placed into an incubator (CELM ${ }^{\circledR}$ C-90, 235 series) and immersed in Tris-Glycine buffer, $\mathrm{pH} 9.5$. Subsequently, the gel was subjected to an electric potential generated by the CELM ${ }^{\circledR}$ FEA 250 (158 series) device for 20 minutes. Once completed, the agarose gels were stained and the concentrations of the protein fractions were determined by densitometry with the CanoScan 640P ex device, which was run by using a computer program. The laboratory staff was blinded to the results of physical examination, to the experimental group from which the blood sample had been drawn, and to the nutritional condition of the dogs studied.

The association between the NS of the hospitalized animals and the clinical, laboratory, and electrophoretic variables, classified into categories, was analyzed by using the chi-square $(\chi 2)$ or Fisher's exact test when the expected frequency (Eij) was less than 5. The Kruskal-Wallis (K-W) test was used for continuous variables. The nonparametric test was selected because of the non-normality of the data; the normality of the data was determined for each NS within each disease score group by using the Shapiro-Wilk test. The categorical variables are presented as absolute frequencies, percentages, and continuous variables as the averages, standard deviation, median, and quartiles 3 and 1 . The analyses were performed by using SAS version 8.2 (Software Institute Inc., Cary, NC).

\section{Results and Discussion}

Of the 215 dogs studied, 29.76\% (64/215) had severe clinical malnutrition (SCM), 24.65\% (53/215) had moderate clinical malnutrition (MCM), and $45.58 \%$ (98/215) were clinically well nourished
$(\mathrm{CWN})$. For the hospitalized patients, 33.33\% had SCM (62/186), 26.35\% had MCM (49/186), and $40.32 \%$ were CWN (75/186), i.e., the prevalence of clinical malnutrition was $59.68 \%$. These data are consistent with those of other human and veterinary medicine studies (CHANDLER; GRECO; FETTMAN, 1992; MCWHIRTER; PENNINGTON, 1994; VANNUCCHI; UNAMUNO; MARCHINI, 1996).

The results showed a strong association between malnutrition and the severity of the underlying disease. The prevalence of malnutrition was $20.7 \%$ in the clinical control group (G1), $57.14 \%$ in the moderate disease group (G2), and $71.87 \%$ in the severe disease group (G3). Thus, G1 was composed mainly of CWN dogs and G2 and G3 (hospitalized animals) were composed of malnourished dogs (Table 2).

Regarding clinical variables, the BMI values for G1 were indicative of ideal weight (Table 3). For animals with moderate disease (G2), the association between NS and BMI was statistically significant. The BMI values in the SCM group had median values below the normal reference, indicating that most of these animals were underweight and below the reference medians indicative of the ideal weight for the MCM and CWN (Table 3) groups. In malnourished animals, a low BMI reinforces the diagnosis of malnutrition and indicates that the adipose tissue and/or lean body mass may be reduced (GARCIA; KENNEDY, 1994; MONDINI; MONTEIRO, 1998; MULLER; PINHEIRO; MENDONÇA, 2008).

BMI was not statistically associated with NS in the G3 animals (Table 3); this probably resulted from the small sample size $(\mathrm{n}=32)$ and the large variation in the values for this group, as evidenced by the high standard deviation of the mean. Another possible explanation is that animals in critical condition most often have edema and effusions, which masks the loss of muscle mass or fat and leads to overestimation of the BMI of 
these animals (FONTOURA et al., 2006; MAICÁ; SCHWEIGERT, 2008). In fact, $12.5 \%$ of G3 animals had edema or effusions, while only $2 \%$ of the cases in G2 and none of the cases in G1 had either of these conditions. Although not statistically significant, the median BMI for the SCM group was below the reference values in G3, whereas the MCM group had values indicative of ideal weight and the CWN group had values indicative of being overweight. Therefore, this index succeeded in confirming weight reduction in animals with SCM, which became evident when compared to the other groups ( $\mathrm{MCM}$ and $\mathrm{CWN}$ ), suggesting that the measurement is valid.

In G1, G2, and G3, more than half of the animals had an opaque coat $(65.22 \%,>69 \%$, and $>71 \%)$ without shedding $(56.52 \%, \geq 50 \%$, and $42.8 \%)$, with uniform hairy coverage $(86.96 \%,>80 \%$, and $>77.7 \%$ ), and a balanced proportion of smooth or rough coat, respectively. The homogeneity of the characteristics of the skin and coats of dogs with different NS classifications probably stems from the fact that skin changes become apparent only months after nutritional deficiency (WATSON, 1998).

Regarding hematological variables, a positive association was observed between malnutrition and the corpuscular volume $(\mathrm{CV})$ of hospitalized dogs. The control group and the CWN animals (G2 and G3) had mean and median $\mathrm{CV}$ values within the reference ranges, i.e., not anemic (Tables 4 and 5). The MCM and SCM groups exhibited anemia, and these traits were more intense in G3.

Table 4. Association between nutritional status and hematological variables, in mean and median (Q3-Q1), for the clinically well-nourished dogs in the control group (G1) treated at the Veterinary Hospital of the Universidade Estadual de Londrina, from August 2011 to August 2012. Londrina, 2013.

\begin{tabular}{ccc}
\hline Variable & $\begin{array}{c}\text { Clinically Well Nourished } \\
\mathrm{n}=23\end{array}$ & Reference Values * \\
\hline Corpuscular Volume $(\%)$ & $41.2 \pm 9.7$ & \\
Mean $\pm \mathrm{SD}$ & $39.6(46.8-34.0)$ & $33-55$ \\
Median & $12.7 \pm 3.4$ & \\
Hemoglobin $(\mathrm{g} / \mathrm{dL})$ & $12.7(14.5-10.2)$ & $12-18$ \\
Mean $\pm \mathrm{SD}$ & $1,751.1 \pm 1,970.1$ & \\
Median & $1,418.0(1,901.9-740.0)$ & $1,000-4,800$ \\
Lymphocytes $($ units $/ \mu \mathrm{L})$ &
\end{tabular}

${ }^{*}$ BUSH (2004).

Source: Elaboration of the authors.

Further, a significant association was found between the hemoglobin concentration $(\mathrm{Hb})$ and NS. The control group had normal $\mathrm{Hb}$ concentrations (Table 4). Although all G2 animals had low serum concentrations, these values were higher in the CWN group and lower in the SCM group (Table 5). In $\mathrm{G} 3$, the $\mathrm{Hb}$ was markedly decreased in the MCM group and was even more strikingly decreased in the SCM group. The CWN animals displayed $\mathrm{Hb}$ medians at the lower limit of the reference range (Table 5).
The association between malnutrition and anemia is well known, and this is the most frequent normocytic and normochromic classification (BACH-NGOHOU et al., 1998; FONTOURA et al., 2006). Some of the purely nutritional causes of anemia in humans are deficiency in iron (resulting in microcytic hypochromic anemia), folate, or cobalamin. Anemia may also be due to inflammatory disease in sick, malnourished animals (PRINS, 2010). 
Table 5. Association between nutritional status and hematological variables, in mean and median (Q3-Q1), for hospitalized dogs (G2 and G3), from August 2011 to August 2012, at the Medical Clinic of Companion Animals, the Veterinary Hospital of the Universidade Estadual de Londrina. London, 2013.

\begin{tabular}{|c|c|c|c|c|}
\hline Variable & $\begin{array}{c}\begin{array}{c}\text { Severe Clinical } \\
\text { Malnutrition }\end{array} \\
\mathrm{G} 2, \mathrm{n}=46 ; \mathrm{G} 3, \mathrm{n}=16\end{array}$ & $\begin{array}{c}\begin{array}{c}\text { Moderate Clinical } \\
\text { Malnutrition }\end{array} \\
\mathrm{G} 2, \mathrm{n}=42 ; \mathrm{G} 3, \mathrm{n}=7\end{array}$ & $\begin{array}{c}\begin{array}{c}\text { Clinically well } \\
\text { nourished }\end{array} \\
\mathrm{G} 2, \mathrm{n}=66 ; \mathrm{G} 3, \mathrm{n}=9\end{array}$ & Analysis \\
\hline \multicolumn{4}{|c|}{ Corpuscular Volume (\%) (G2) ${ }^{1}$} & $\mathrm{~K}-\mathrm{W} *$ \\
\hline $\begin{array}{c}\text { Mean } \pm \\
\text { SD }\end{array}$ & $28.5 \pm 10.8$ & $30.3 \pm 12.6$ & $33.9 \pm 13.3$ & $\begin{array}{c}\chi^{2}=6.90 \\
\mathrm{DF}=2\end{array}$ \\
\hline Median & $28.6(34.8-21.0)$ & $28.2(34.8-21.8)$ & $37.0(43.6-23.5)$ & $\mathbf{p}=\mathbf{0 . 0 3 2}$ \\
\hline \multicolumn{4}{|c|}{ Corpuscular Volume (\%) (G3) } & K-W \\
\hline $\begin{array}{c}\text { Mean } \pm \\
\text { SD }\end{array}$ & $21.2 \pm 10.7$ & $19.7 \pm 8.0$ & $35.4 \pm 11.8$ & $\begin{array}{c}\chi^{2}=7.66 \\
\mathrm{DF}=2\end{array}$ \\
\hline Median & $17.5(28.1-14.7)$ & $19,9(27,0-11,0)$ & $37.1(41.4-25.5)$ & $\mathbf{p}=\mathbf{0 . 0 2 2}$ \\
\hline \multicolumn{4}{|c|}{ Hemoglobin $(\mathrm{g} / \mathrm{dL})(\mathbf{G} 2)^{2}$} & $\mathrm{~K}-\mathrm{W}$ \\
\hline $\begin{array}{c}\text { Mean } \pm \\
\text { SD }\end{array}$ & $8.7 \pm 3.2$ & $9.6 \pm 4.0$ & $10.4 \pm 4.0$ & $\begin{array}{c}\chi 2=7.05 \\
\mathrm{DF}=2\end{array}$ \\
\hline Median & $8.6(11.0-6.6)$ & $9.1(11.1-7.2)$ & $11.1(13.3-6.8)$ & $p=0.029$ \\
\hline \multicolumn{4}{|c|}{ Hemoglobin (g/dL) (G3) } & $\mathrm{K}-\mathrm{W}$ \\
\hline $\begin{array}{c}\text { Mean } \pm \\
\text { SD }\end{array}$ & $6.3 \pm 3.4$ & $5.8 \pm 2.4$ & $10.7 \pm 3.5$ & $\begin{array}{c}\chi 2=8.76 \\
D F=2\end{array}$ \\
\hline Median & $5.1(8.5-4.0)$ & $5.8(8.6-3.1)$ & $12.0(13.1-7.1)$ & $\mathbf{p}=\mathbf{0 . 0 1 3}$ \\
\hline \multicolumn{4}{|c|}{ Lymphocytes (units $/ \mu \mathrm{L})(\mathbf{G} 2)^{3}$} & K-W \\
\hline $\begin{array}{c}\text { Mean } \pm \\
\text { SD }\end{array}$ & $2,694.0 \pm 6,718.6$ & $2,279.3 \pm 1,839.3$ & $1,701.0 \pm 1,293.9$ & $\begin{array}{c}\chi 2=1.60 \\
\mathrm{DF}=2\end{array}$ \\
\hline Median & $1,440.0(1,925.0-822.0)$ & $1,860.0(3,395.0-732.0)$ & $1,317.1(2,396.0-742.5)$ & $\mathrm{p}=0.4492$ \\
\hline \multicolumn{4}{|c|}{ Lymphocytes (units/ $\mu \mathrm{L})$ (G3) } & $\mathrm{K}-\mathrm{W}$ \\
\hline $\begin{array}{c}\text { Mean } \pm \\
\text { SD }\end{array}$ & $826.2 \pm 665.8$ & $1,507.1 \pm 1,588.5$ & $1,562.1 \pm 1,515.8$ & $\begin{array}{c}\chi 2=1.25 \\
\mathrm{DF}=2\end{array}$ \\
\hline Median & $722.0(1,115.5-312.5)$ & $1,058.0(3,376.0-85.0)$ & $760.0(1,182.0-654.0)$ & $\mathrm{p}=0.536$ \\
\hline
\end{tabular}

${ }^{1}$ Reference values: $37-55 \%$ (BUSH, 2004). ${ }^{2}$ Reference values: $12-18$ g/dL (BUSH, 2004). ${ }^{3}$ Reference values: $1,000-4,800 / \mu \mathrm{L}$ (BUSH, 2004).

$* \mathrm{~K}-\mathrm{W}=$ Kruskal-Wallis test, $\chi 2=$ chi-square test, $\mathrm{DF}=$ degrees of freedom.

Source: Elaboration of the authors.

The number of circulating lymphocytes (CBL) was not correlated with the NS, and this was probably due to the large variation of the values found in all groups, as evidenced by the high standard deviation of the mean and median (Table 5). The number of CBL are also influenced by non-nutritional factors like the effects of the underlying disease, trauma, bleeding, stress, and drugs (such as cimetidine, steroids, and immunosuppressants), so its use as a nutritional marker in critically ill patients is not recommended (JEEJEEBHOY, 2000; MAICÁ; SCHWEIGERT, 2008; OLIVEIRA; ROCHA; SILVA, 2008; PRINS, 2010). Coppini et al. (2006) also observed no association between malnutrition and lymphopenia in hospitalized humans.

Fibrinogen is an acute-phase protein synthesized by the liver, and several studies reported that it is a significant inflammatory marker for dogs as well as for horses (SUTTON; JOHNSTONE, 1977; ANDREWS; REAGAN; DeNICOLA, 1994). In G2, this parameter was associated with malnutrition; the frequency of fibrinogen concentrations above the reference values was higher in malnourished animals, especially in the SCM group (26.83\%), whereas the value was only $8.64 \%$ in CWN animals (Table 6). 
Table 6. Association between nutritional status and fibrinogen concentration, frequency (\%), for dogs treated at the Veterinary Hospital of the Universidade Estadual de Londrina, from August 2011 to August 2012. Londrina, 2013.

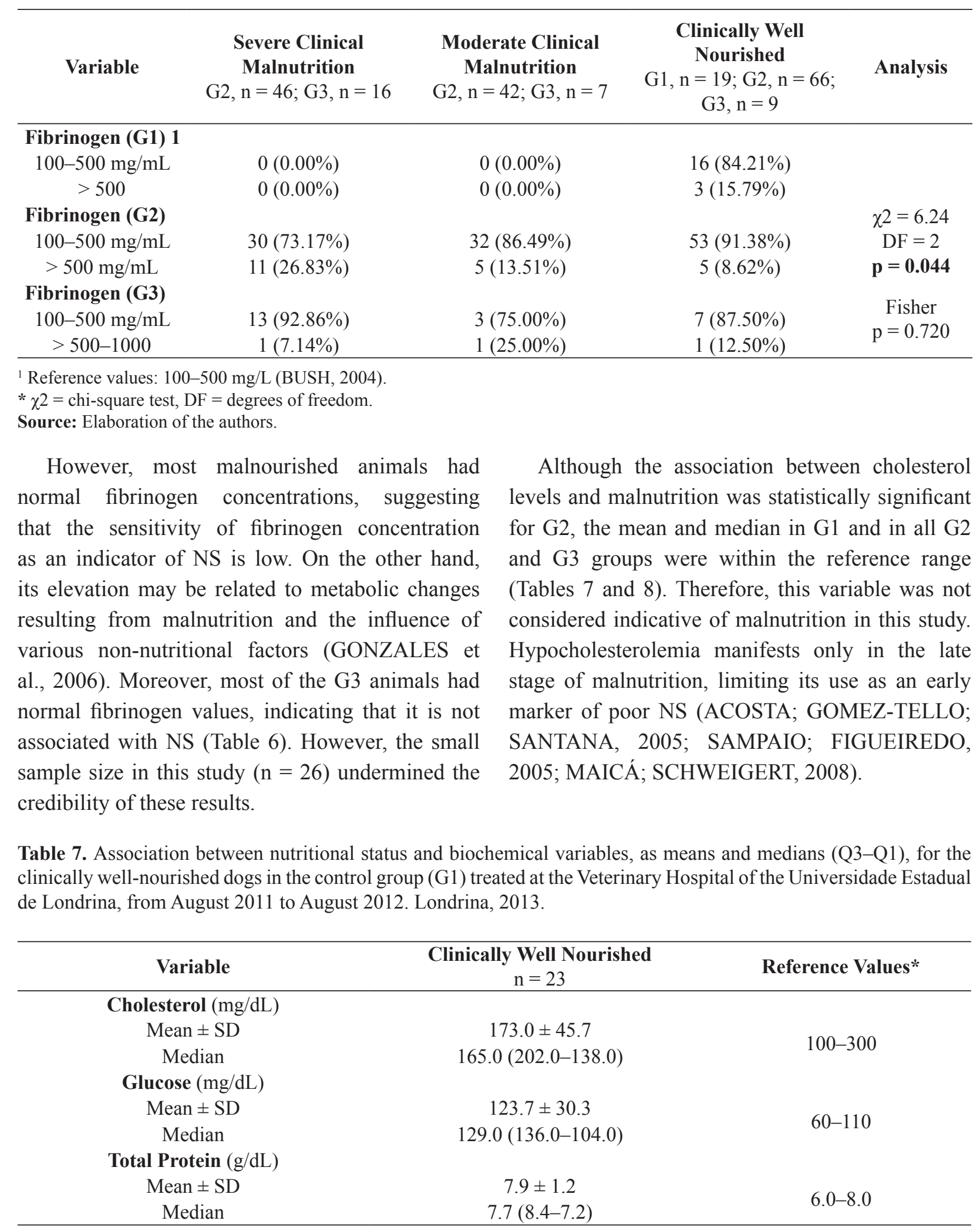

\footnotetext{
* BUSH (2004).
}

Source: Elaboration of the authors. 
Table 8. Association between nutritional status and biochemical variables, in means and medians (Q3-Q1), for hospitalized dogs (G2 and G3), from August 2011 to August 2012, at the Medical Clinic of Companion Animals, the Veterinary Hospital of the Universidade Estadual de Londrina. Londrina, 2013.

\begin{tabular}{|c|c|c|c|c|}
\hline Variable & $\begin{array}{c}\begin{array}{c}\text { Severe Clinical } \\
\text { Malnutrition }\end{array} \\
\mathrm{G} 2, \mathrm{n}=46 ; \mathrm{G} 3, \mathrm{n}=16\end{array}$ & $\begin{array}{c}\text { Moderate Clinical } \\
\quad \text { Malnutrition } \\
\mathrm{G} 2, \mathrm{n}=42 ; \mathrm{G} 3, \mathrm{n}=7\end{array}$ & $\begin{array}{c}\begin{array}{c}\text { Clinically Well } \\
\text { Nourished }\end{array} \\
\mathrm{G} 2, \mathrm{n}=66 ; \mathrm{G} 3, \mathrm{n}=9\end{array}$ & Analysis \\
\hline \multicolumn{4}{|c|}{ Cholesterol (mg/dL) (G2) ${ }^{1}$} & $\mathrm{~K}-\mathrm{W} *$ \\
\hline Mean \pm SD & $232.9 \pm 90.4$ & $180.2 \pm 71.8$ & $214.0 \pm 71.6$ & $\chi 2=9.38$ \\
\hline Median & $228(303-173)$ & $169(238-134)$ & $218(268-169)$ & $\begin{array}{c}D F=2 \\
\mathbf{p}=\mathbf{0 . 0 0 9}\end{array}$ \\
\hline \multicolumn{4}{|c|}{ Cholesterol (mg/dL) (G3) } & $\mathrm{K}-\mathrm{W}$ \\
\hline Mean \pm SD & $254.6 \pm 104.8$ & $216.9 \pm 91.5$ & $184.3 \pm 79.0$ & $\begin{array}{c}\chi 2=3.23 \\
D F=2\end{array}$ \\
\hline Median & $262.5(316.0-166.5)$ & $245.0(277.0-152.0)$ & $158.0(243.0-118.0)$ & $\mathrm{p}=0.199$ \\
\hline \multicolumn{4}{|c|}{ Glucose $(\mathrm{mg} / \mathrm{dL})(\mathbf{G} 2)^{2}$} & $\mathrm{~K}-\mathrm{W}$ \\
\hline Mean \pm SD & $102.5 \pm 34.1$ & $116.0 \pm 45.2$ & $119.0 \pm 62.4$ & $\begin{array}{c}\chi 2=2.66 \\
\mathrm{DF}=2\end{array}$ \\
\hline Median & $100(121-87)$ & $101(131-92)$ & $105(123-93)$ & $\mathrm{p}=0.265$ \\
\hline \multicolumn{4}{|c|}{ Glucose $(\mathrm{mg} / \mathrm{dL})(\mathbf{G} 3)$} & $\mathrm{K}-\mathrm{W}$ \\
\hline Mean \pm SD & $107.1 \pm 52.5$ & $174.3 \pm 176.6$ & $98.9 \pm 29.9$ & $\begin{array}{c}\chi 2=0.98 \\
\mathrm{DF}=2\end{array}$ \\
\hline Median & $104.5(116.5-71.0)$ & $106.0(141.0-92.0)$ & $110.0(116.0-100.0)$ & $\mathrm{p}=0.612$ \\
\hline \multicolumn{4}{|c|}{ Total Protein $(\mathrm{g} / \mathrm{dL})(\mathbf{G} 2)^{3}$} & $\mathrm{~K}-\mathrm{W}$ \\
\hline Mean \pm SD & $6.9 \pm 2.0$ & $6.5 \pm 1.9$ & $7.0 \pm 1.4$ & $\begin{array}{c}\chi^{2}=3.34 \\
\mathrm{DF}=2\end{array}$ \\
\hline Median & $6.9(7.9-5.6)$ & $6.5(7.6-5.0)$ & $7.1(7.9-6.2)$ & $\mathrm{p}=0.188$ \\
\hline \multicolumn{4}{|c|}{ Total Protein (g/dL) (G3) } & $\mathrm{K}-\mathrm{W}$ \\
\hline Mean \pm SD & $6.7 \pm 1.3$ & $5.4 \pm 1.4$ & $6.7 \pm 1.7$ & $\begin{array}{c}\chi^{2}=4.37 \\
\mathrm{DF}=2\end{array}$ \\
\hline Median & $6.7(8.0-5.6)$ & $5.0(7.1-4.6)$ & $6.6(8.2-5.1)$ & $\mathrm{p}=0.116$ \\
\hline
\end{tabular}

${ }^{1}$ Reference values: 100-300 mg/dL (BUSH, 2004). ${ }^{2}$ Reference values: $60-110 \mathrm{mg} / \mathrm{dL}$ (BUSH, 2004). ${ }^{3}$ Reference values: $6.0-8.0$ $\mathrm{g} / \mathrm{dL}$ (BUSH, 2004).

$* \mathrm{~K}-\mathrm{W}=$ Kruskal-Wallis test, $\chi 2$ = chi-square test, $\mathrm{DF}=$ degrees of freedom.

Source: Elaboration of the authors.

Biochemical analysis of serum samples from sick animals showed no statistically significant association between malnutrition and glucose and total protein (Table 8). Although the total serum protein values for sick animals were lower than those of control animals (Tables 7 and 8), the concentrations were within the reference range in G2 and decreased only in the MCM group from G3.

While a decrease in serum proteins might be a good indicator of chronic protein-energy malnutrition, several factors other than nutrition can modify their concentrations, such as hydration status, liver disease, increased catabolism, infection, or inflammation (BUSH, 2004; PRINS, 2010). Moreover, some proteins have a long half-life, which reduces the drop in the concentrations of these proteins during fasting (MAULDIN; DAVIDSON, 2007; ECKERSALL, 2008). Therefore, total protein is considered a less sensitive and nonspecific marker of malnutrition (VANNUCCHI; UNAMUNO; MARCHINI, 1996; SITGES-SERRA; SANTOS et al., 2003; CHANDLER; GUNN-MOORE, 2004; ACOSTA; GOMEZ-TELLO; SANTANA, 2005; OLIVEIRA; ROCHA; SILVA, 2008). Other studies have found no significant differences in 
the concentrations of total protein in healthy and malnourished individuals (DAHAN; JACOBS; SMITH, 1984; ASSEM et al., 1994; BENJAMIN, 1989; HASSANEIN et al., 1998; CHANDLER; GUNN-MOORE, 2004).

The electrophoretic analysis of samples from healthy dogs showed no significant changes
(Table 9). In contrast, an association was observed between the albumin fraction and malnutrition for hospitalized dogs (Table 10). This fraction was decreased in all NS groups; the CWN group had higher median and mean values, whereas the SCM group had the lowest values (Table 10). The values for $\mathrm{G} 3$ were lower than those of G2.

Table 9. Association between nutritional status and electrophoretic variables, in means and median (Q3-Q1), for the clinically well-nourished dogs in the control group (G1) treated at the Veterinary Hospital of the Universidade Estadual de Londrina, from August 2011 to August 2012. Londrina, 2013.

\begin{tabular}{|c|c|c|}
\hline Variable & $\begin{array}{l}\text { Clinically Well Nourished } \\
\qquad \mathrm{n}=23\end{array}$ & Reference Values * \\
\hline \multicolumn{3}{|c|}{ Albumin (g/dL) } \\
\hline Mean \pm SD & $2.83 \pm 0.52$ & \multirow{2}{*}{$2.5-4$} \\
\hline Median & $2.81(3.02-2.50)$ & \\
\hline \multicolumn{3}{|c|}{ Alpha1-globulin (g/dL) } \\
\hline Mean \pm SD & $1.26 \pm 0.91$ & \multirow{2}{*}{$0.2-0.5$} \\
\hline Median & $0.83(2.08-0.59)$ & \\
\hline \multicolumn{3}{|c|}{ Alpha 2-globulin (g/dL) } \\
\hline Mean \pm SD & $1.02 \pm 0.67$ & \multirow{2}{*}{$0.3-1.1$} \\
\hline Median & $0.77(1.32-0.56)$ & \\
\hline \multicolumn{3}{|c|}{ Beta-globulin $(\mathrm{g} / \mathrm{dL})$} \\
\hline Mean \pm SD & $1.74 \pm 0.87$ & \multirow{2}{*}{$1.2-2.2$} \\
\hline Median & $1.65(2.05-1.20)$ & \\
\hline \multicolumn{3}{|c|}{ Gamma-globulin (g/dL) } \\
\hline Mean \pm SD & $1.03 \pm 0.85$ & \multirow{2}{*}{$0.8-1.8$} \\
\hline Median & $0.77(1.20-0.46)$ & \\
\hline
\end{tabular}

* BUSH (2004).

Source: Elaboration of the authors.

The albumin concentration may be low in malnutrition and various diseases such as kidney disease, liver disease, protein-losing enteropathy, and lymphoma, among others (BUSH, 2004). The decrease of this fraction suggests chronic malnutrition and indicates poor prognosis (BUSH, 2004; FONTOURA et al., 2006; MAULDIN; DAVIDSON, 2007; OLIVEIRA; ROCHA; SILVA, 2008; TORRES FILHO, 2008).
The gamma-globulin fraction consists of the immunoglobulins, especially IgG (LARSON, 1974). Control animals had normal gamma-globulin fractions (Table 9). For G2, a positive association was found between the gamma fraction and NS (Table 10). In G2 and G3, the MCM and CWN groups displayed normal values, and the means and medians of the SCM groups were above the reference values (Table 10). 
Table 10. Association between nutritional status and electrophoretic variables, in means and medians (Q3-Q1), for hospitalized dogs, from August 2011 to August 2012, at the Medical Clinic of Companion Animals, the Veterinary Hospital of the Universidade Estadual de Londrina. Londrina, 2013.

\begin{tabular}{|c|c|c|c|c|}
\hline Variable & $\begin{array}{c}\text { Severe Clinical } \\
\text { Malnutrition } \\
n=46\end{array}$ & $\begin{array}{l}\text { Moderate Clinical } \\
\text { Malnutrition } \\
n=42\end{array}$ & $\begin{array}{c}\text { Clinically Well } \\
\text { Nourished } \\
n=66\end{array}$ & Analysis \\
\hline \multicolumn{4}{|l|}{ Albumin (G2) ${ }^{1}$} & \multirow{3}{*}{$\begin{array}{c}\mathrm{K}-\mathrm{W} * \\
\chi 2=7.52 ; \mathrm{DF}=2 \\
\mathbf{p}=\mathbf{0 . 0 2 3}\end{array}$} \\
\hline Mean \pm SD & $1.93 \pm 0.68$ & $2.24 \pm 0.83$ & $2.37 \pm 0.84$ & \\
\hline Median & $1.83(2.48-1.33)$ & $2.14(2.69-1.64)$ & $2.24(2.58-1.76)$ & \\
\hline \multicolumn{4}{|l|}{ Albumin (G3) } & \multirow{3}{*}{$\begin{array}{c}\mathrm{K}-\mathrm{W} \\
\chi 2=6.03 ; \mathrm{DF}=2 \\
\mathbf{p}=\mathbf{0 . 0 4 9}\end{array}$} \\
\hline Mean \pm SD & $1.74 \pm 0.59$ & $1.42 \pm 0.61$ & $2.24 \pm 0.56$ & \\
\hline Median & $1.62(2.05-1.45)$ & $1.45(1.88-0.92)$ & $2.34(2.61-1.94)$ & \\
\hline \multicolumn{4}{|c|}{ Alpha1-globulin (G2) ${ }^{2}$} & \multirow{3}{*}{$\begin{array}{c}\mathrm{K}-\mathrm{W} \\
\chi 2=3.52 ; \mathrm{DF}=2 \\
\mathrm{p}=0.172\end{array}$} \\
\hline Mean \pm SD & $0.26 \pm 0.39$ & $0.37 \pm 0.56$ & $0.35 \pm 0.45$ & \\
\hline Median & $0.15(0.27-0.08)$ & $0.24(0.84-0.12)$ & $0.19(0.38-0.01)$ & \\
\hline \multicolumn{4}{|c|}{ Alpha1-globulin (G3) } & \multirow{3}{*}{$\begin{array}{c}\mathrm{K}-\mathrm{W} \\
\chi 2=1.71 ; \mathrm{DF}=2 \\
\mathrm{p}=0.426\end{array}$} \\
\hline Mean \pm SD & $0.29 \pm 0.23$ & $0.28 \pm 0.17$ & $0.18 \pm 0.08$ & \\
\hline Median & $0.26(0.33-0.14)$ & $0.35(0.39-0.09)$ & $0.14(0.23-0.12)$ & \\
\hline \multicolumn{4}{|c|}{ Alpha 2-globulin $(G 2)^{3}$} & \multirow{3}{*}{$\begin{array}{c}\mathrm{K}-\mathrm{W} \\
\chi 2=3.25 ; \mathrm{DF}=2 \\
\mathrm{p}=0.197\end{array}$} \\
\hline Mean \pm SD & $1.04 \pm 0.78$ & $1.18 \pm 0.78$ & $1.31 \pm 0.81$ & \\
\hline Median & $0.90(1.58-0.33)$ & $1.02(1.71-0.56)$ & $1.26(1.88-0.62)$ & \\
\hline \multicolumn{4}{|c|}{ Alpha 2-globulin (G3) } & \multirow{3}{*}{$\begin{array}{c}\mathrm{K}-\mathrm{W} \\
\chi 2=1.52 ; \mathrm{DF}=2 \\
\mathrm{p}=0.468\end{array}$} \\
\hline Mean \pm SD & $1.17 \pm 0.71$ & $0.78 \pm 0.66$ & $1.19 \pm 1.09$ & \\
\hline Median & $1.19(1.84-0.66)$ & $0.82(1.11-0.10)$ & $0.95(2.05-0.19)$ & \\
\hline \multicolumn{4}{|c|}{ Beta-globulin (G2) ${ }^{4}$} & \multirow{3}{*}{$\begin{array}{c}\mathrm{K}-\mathrm{W} \\
\chi 2=4.83 ; \mathrm{DF}=2 \mathrm{p} \\
=0.089\end{array}$} \\
\hline Mean \pm SD & $1.23 \pm 0.57$ & $1.16 \pm 0.75$ & $1.45 \pm 0.71$ & \\
\hline Median & $1.17(1.61-0.91)$ & $0.96(1.67-0.60)$ & $1.37(1.81-0.98)$ & \\
\hline \multicolumn{4}{|c|}{ Beta-globulin (G3) } & \multirow{3}{*}{$\begin{array}{c}\mathrm{K}-\mathrm{W} \\
\chi 2=3.88 ; \mathrm{DF}=2 \\
\mathrm{p}=0.144\end{array}$} \\
\hline Mean \pm SD & $1.55 \pm 0.63$ & $0.98 \pm 0.35$ & $1.81 \pm 1.19$ & \\
\hline Median & $1.43(1.8-0.92)$ & $0.87(1.35-0.74)$ & $1.75(1.91-1.38)$ & \\
\hline \multicolumn{4}{|c|}{ Gamma-globulin (G2) ${ }^{5}$} & \multirow{3}{*}{$\begin{array}{c}\mathrm{K}-\mathrm{W} \\
\chi 2=5.96 ; \mathrm{DF}=2 \mathbf{p} \\
=\mathbf{0 . 0 5 0}\end{array}$} \\
\hline Mean \pm SD & $2.44 \pm 2.21$ & $1.64 \pm 1.40$ & $1.56 \pm 1.33$ & \\
\hline Median & $1.91(3.32-0.79)$ & $1.07(2.38-0.58)$ & $1.15(1.91-1.15)$ & \\
\hline \multicolumn{4}{|c|}{ Gamma-globulin (G3) } & \multirow{3}{*}{$\begin{array}{c}\mathrm{K}-\mathrm{W} \\
\chi 2=2.87 ; \mathrm{DF}=2 \\
\mathrm{p}=0.238\end{array}$} \\
\hline Mean \pm SD & $2.30 \pm 1.60$ & $1.70 \pm 0.84$ & $1.28 \pm 0.9$ & \\
\hline Median & $2.29(3.11-0.80)$ & $1.60(2.28-0.86)$ & $1.19(1.39-1.00)$ & \\
\hline
\end{tabular}

${ }^{1}$ Reference values: 2.5-4.0 g/dL (BUSH, 2004). ${ }^{2}$ Reference values: 0.2-0.5 g/dL (BUSH, 2004). ${ }^{3}$ Reference values: $0.3-1.1 \mathrm{~g} / \mathrm{dL}$ (BUSH, 2004). ${ }^{4}$ Reference values: $1.2-2.2 \mathrm{~g} / \mathrm{dL}$ (BUSH, 2004).

${ }^{5}$ Reference Values: $0.8-1.8 \mathrm{~g} / \mathrm{dL}$ (BUSH, 2004).

$* \mathrm{~K}-\mathrm{W}=$ Kruskal-Wallis test, $\chi 2=$ chi-square test, $\mathrm{DF}=$ degrees of freedom.

Source: Elaboration of the authors. 
Gamma-globulin increases whenever an inflammatory, infectious, or immune reaction is present. Additionally, malnourished patients are less likely to overcome infections and are predisposed to persistent inflammation (REILLY et al., 1988, 1995; REMILLARD; ROUDEBUSH, 2000; SILVA; LOPES; FARIA, 2008). Thus, it is possible that severely malnourished animals have been affected by more severe or lasting inflammation, where the persistence of antigens has served as a stimulus for increased production of gamma-globulins (BUSH, 2004).

\section{Conclusions}

The severity of malnutrition was strongly associated with the severity of the underlying disease in hospitalized dogs.

In the evaluated dogs, greater disease severity was associated with a higher prevalence and severity of malnutrition.

The prevalence of clinical malnutrition in hospitalized dogs was about $60 \%$, and lower BMI values, anemia, low hemoglobin concentration, hyperfibrogenemia, decreased albumin fraction, and increased gamma-globulin (by electrophoresis) were associated with malnutrition, reinforcing the classification of NS. Moreover, the BMI, CV, $\mathrm{Hb}$, and albumin fraction values were decreased when the BCS and MMS classification were lower, suggesting that these are valid indicators of malnutrition. BMI and increased gamma-globulin fraction were associated with severe malnutrition.

The fibrinogen concentration was not an indicator of NS.

\section{Acknowledgments}

We thank the interns who assisted in data collection (Priscila dos Santos, Talita Bianca Brunharo, Ana Carolina Buzzo, and Caroline Spera) and the National Council for Scientific and
Technological Development $(\mathrm{CNPq})$ for funding the project.

\section{References}

ACOSTA, E. J.; GOMEZ-TELLO, V.; SANTANA, R. S. Nutritional assessment of the severely ill patient. Nutrición Hospitalaria, Madrid, v. 20, n. 2, p. 5-8, 2005.

ANDREWS, D. A.; REAGAN, W. J.; DeNICOLA, D. B. Plasma fibrinogen in recognizing equine inflammatorty disease. Continuing Education for the Practicing Veterinarian, Yardley, v. 16, n. 10, p. 1349-1357, 1994.

BASIC stardarts for pre-anesthesia care. In: ASA guidelines, stardarts and statmentes. Illinois: American Society of Anesthesiologist, ASA, 1984.

ASSEM, H.; ABDEL, F. M.; MAHDY, N.; SHARAKY, O. Plasma fibronectin, serum apoproteins, albumin and transferring concentrations during nutritional repletion in protein energy malnutrition. Egyptian Society of Pediatric Allergy and Immunology, Cairo, v. 2, n. 13, p. 209-24, 1996.

BACH-NGOHOU, K.; BETTEMBOURG, A.; LE CARRER, D.; MASSON, D.; DENIS, M. Évaluation clinico-biologique de la dénutrition. Annales de Biologie Clinique, Paris, v. 62, n. 4, p. 395-403, 2004.

BATEMAN, S. W.; CHEW, D. J. Fluid therapy for dogs and cats. In: . Saunders manual of small animal practice. $3^{\text {th }}$ ed. St. Louis: Saunders Elsevier, 2006. cap. 5, p. 82-99.

BENJAMIN, D. Laboratory tests and nutritional assessment. Pediatric Clinics of North America, Maryland Heights, v. 36, n. 1, p. 139-56, 1989.

BRUNETTO, M. A. Avaliação de suporte nutricional sobre a alta hospitalar em cães e gatos. 2006. Dissertação (Mestrado em Clínica Médica Veterinária) - Universidade Estadual Paulista Júlio de Mesquita Filho, Jaboticabal.

Effects of nutritional support on hospital outcome in dogs and cats. Journal of veterinary Emergency and Critical Care, San Antonio, v. 20, n. 2, p. 224-231, 2010.

BUSH, B. M. Nutrientes e metabólicos. In: Interpretação de resultados laboratoriais para clínicos de pequenos animais. São Paulo: Roca, 2004. cap. 5, p. 180-191.

CHANDLER, M. L.; GRECO, D. S.; FETTMAN, M. J. Hypermetabolism in illness and injury. Compendium on Continuing Education for the Practising Veterinarian, Yardley, v. 14, n. 14, p. 1284-1290, 1992. 
CHANDLER, M. L.; GUNN-MOORE, D. A. Nutritional status of canine and feline patients admitted to a referral veterinary internal medicine service. Journal of Nutrition, Bethesda, v. 134, n. 8, p. 2050S-2052S, 2004.

COPPINI, L. Z.; WAITZBERG, D. L.; FERRINI, M. T.; SILVA, M. L. T.; GAMA-RODRIGUES, J.; CIOSAK, S. L. Comparação da avaliação nutricional subjetiva global x avaliação nutricional objetiva. Revista da Associação Médica Brasileira, São Paulo, v. 41, n. 1, p. 6-10, 1995.

DAHAN, M. S.; JACOBS, L.; SMITH, S. The significance of hypoalbuminemia following injury and infection. The American Journal of Surgery, Birmingham, v. 51, n. 6, p. 362-365, 1985.

ECKERSALL, P. D. Proteins, proteomics and the dysproteinemias. In: KANEKO, J. J.; HARVEY, J. W.; BRUSS, M. L. Clinical biochemistry of domestic animals. $6^{\text {th }}$ ed. Burlington: Academic Press, 2008. cap. 5, p. 117-155.

FONTOURA, C. S. M.; CRUZ, D. O.; LONDERO, L. G.; VIEIRA, R. M. Avaliação nutricional de paciente critico. Revista Brasileira de Terapia Intensiva, São Paulo, v. 18, n. 3, jul./set. 2006.

FOUQUE, D.; KALANTAR-ZADEH, K.; KOPPLE, J.; CANO, N.; CHAUVEAU, P.; CUPPARI, L.; FRANCH, H.; GUARNIERI, G.; IKIZLER, T. A.; KAYSEN, G.; LINDHOLM, B.; MASSY, Z.; MITCH, W.; PINEDA, E.; STENVINKEL, P.; TREVINHO-BECERRA, A.; WANNE, C. A proposed nomenclature and diagnostic criteria for protein- energy wasting in acute and chronic kidney disease. Kidney International, St. Louis, v. 73, n. 4, p. 391-398, 2008.

GARCIA, M.; KENNEDY, E. Assessing linkages between body mass index and morbidity in adults: evidences from four developing countries. European Journal of Clinical Nutrition, London, v. 48, n. 3, p. 9097, 1994.

GAUDELUS, I. S.; SALOMON, A. S. P.; COLOMB, V.; BRUSSET, M. C.; MOSSER, F. Simple pediatric nutritional risk score to identify children at risk of malnutrition. The American Journal of Clinical Nutrition, Bethesda, v. 72, n. 1, p. 64-70, 2000.

GONZALES, M.; CULEBRAS-FERNANDEZ, J. M.; LORENZO, G.; MATEOS, A. Recommendations for the nutritional assessment of critically ill patients. Revista Médica de Chile, Santiago, v. 8, n. 134, p. 1049-56, 2006.

HASSANEIN, E. S. A.; ASSEM, H. M.; REZK, M. M.; EL-MAGHRABY, R. M. Study of plasma albumin, transferrin, and fibronectin in children with mild to moderate protein-energy malnutrition. Journal of Tropical Pediatrics, Oxford, v. 44, n. 6, p. 362-365, 1998.
JEEJEEBHOY, K. N. Nutritional assessment. Nutrition, Syracuse, v. 2, n. 16, p. 585-590, 2000.

KANEKO, J. J.; SMITH, H. The estimation of plasma fibrinogen and its clinical significance in the dog. The California Veterinarian, California, v. 21, n. 4, p. 21-24, 1967.

LAFLAMME, D. P. Development and validation of a body condition score system for dogs. Canine Practice, Santa Barbara, v. 22, n. 4, p. 10-15, 1997.

LARSON, P. H. Serum proteins: diagnostic significance of electrophoretic patterns. Human Pathology, Madison, v. 5, n. 6, p. 629-640, nov. 1974.

LOGAN, S.; HILDEBRANDT, L. A. The use of prealbumin to enhance nutrition-intervention screening and monitoring of the malnourished patient. Nutrition Today, Boston, v. 38, n. 38, p. 134-135, 2003.

MCWHIRTER, J. P.; PENNINGTON, C. R. Incidence and recognition of malnutrition in hospital. British Medical Journal, London, v. 308, n. 6934, p. 945-948, 1994.

MAICÁ, A. O.; SCHWEIGERT, I. D. Avaliação nutricional em pacientes graves. Revista Brasileira de Terapia Intensiva, São Paulo, v. 20, n. 3, p. 286-295, 2008.

MAULDIN, G. E.; DAVIDSON, J. R. Suporte nutricional em cães e gatos hospitalizados. In: SLATTER, D. Manual de cirugia de pequenos animais. Barueri: Manole, 2007. cap. 5 , p. 87-91.

MEIJERS, J. M. M.; SCHUEREN, M. A. E. B.; SCHOLS, J. M. G. A.; SOETERS, P. B.; HALFENS, R. J. G. Defining malnutrition: Mission or mission impossible? Nutrition, Texas, v. 4, n. 26, p. 432-440, 2010.

MICHEL, K. E; ANDERSON, W.; CUPP, C.; LAFLAMME, D. Validation of a subjective muscle mass scoring system for cats. Journal of Animal Physiology and Animal Nutrition, Oxford, v. 93, n. 6, p. 802-810, 2009.

MONDINI, L.; MONTEIRO, C. A. Relevância epidemiológica da desnutrição e da obesidade em distintas classes sociais: métodos de estudo e aplicação à população brasileira. Revista Brasileira de Epidemiologia, São Paulo, v. 1, n. 1, p. 28-39, 1998.

MUIR, W. W. Considerations for general anesthesia. In: TRANQUILLI, W. J.; THURMON, J. C.; GRIM, K. A. (Org.) Lumb \& Jones's veterinary anesthesia and analgesia. $4^{\text {th }}$ ed. Iowa: Blackwell Publising, 2007. cap. 2, p. 7-30.

MULLER, J. E.; PINHEIRO, M. S.; MENDONÇA, D. C. Adaptação do índice de massa corporal humano para 
cães. Ciência Rural, Santa Maria, v. 38, n. 4, p. 10381043, jul. 2008.

OLIVEIRA, L. M. L.; ROCHA, A. P. C.; SILVA, J. M. A. Avaliação nutricional em pacientes hospitalizados: uma responsabilidade interdisciplinar. Revista Saber Cientifico, Porto Velho, v. 1, n. 1, p. 1-10, 2008.

PRINS, A. Nutritional assessment of the critically ill patient. South African Journal of Clinical Nutrition, Lyttelton, v. 1, n. 23, p. 11-18, 2010.

REILLY, H. M.; MARTINEAU, J. K.; MORAN, A.; KENNEDY, H. Nutritional screening: evaluation and implementation of a simple nutrition risk score. Clinical Nutrition, Texas, v. 5, n. 14, p. 269-273, 1995.

REILLY, J. J.; HULL, S. F.; ALBERT, N.; WALLER, A.; BRINGARDENER, S. Economic impact of malnutrition: a model system for hospitalized patients. Journal of Parenteral and Enteral Nutrition, Thousand Oaks, v. 4, n. 12, p. 372-376, 1988.

REMILLARD, R. L.; ROUDEBUSH, P. Assisted feeding in hospitalized patients: enteral and parenteral nutrition. In: . Small animal clinical nutrition. 4. ed. Topeka, KA: Mark Morris Associates, 2000. p. 351-390.

SAMPAIO, L. R.; FIGUEIREDO, V. C. Correlação entre o índice de massa corporal e os indicadores antropométricos de distribuição de gordura corporal em adultos e idosos. Revista de Nutrição, Campinas, v. 18, n. 1, p. 53-61, 2005.

SANTOS, N. S.; DRAIBE, S. A.; KAMIMURA, M. A.; CANZIANI, M. E.; CENDOROGLO, M.; GABERIEL JÚNIOR, A. G.; CUPPARI, L. Is serum albumin a marker of nutritional status in hemodialysis patients without evidence of inflammation? Artificial Organs, Painesville, v. 8, n. 27, p. 681-686, 2003.
SHIMIZU, R. K.; RABELO, R. C. Cuidados nutricionais na hospitalização intensiva. In: RABELO, R. C.; CROWE, D. T. Fundamentos de terapia intensiva veterinária em pequenos animais: condutas no paciente crítico. Rio de Janeiro: LF Livros de Veterinária LTDA, 2005. cap. 47, p. 437-403.

SILVA, R. O. P.; LOPES, A. F.; FARIA, R. M. D. Eletroforese de proteínas séricas: interpretação e correlação clínica. Revista Médica de Minas Gerais, Minas Gerais, v. 18, n. 2, p. 116-122, 2008.

SITGES-SERRA, A.; FRANCH-ARCAS, G. Nutritional assessment. In: PAYNE-JAMES, J. J.; GRIMBLE, G.; SILK, D. Artificial nutrition support in clinical practice. 2. ed. London: Greenwich Medical Media, 2001. p. 165176.

SPEROTTO, F. M.; SPINELLI, R. B. Avaliação nutricional em idosos independentes de uma instituição de longa permanência no município de Erechim-RS. Revista Perspectiva, Erechim, v. 34, n. 125, p. 105-116, mar. 2010.

SUTTON, R. H.; JOHNSTONE, M. The value of plasma fibrinogen estimations in dogs. A comparison with total leucocyte and neutrophil counts. The Journal of Small Animal Practice, Gloucestershire, v. 4, n. 18, p. 277-281, 1977.

TORRES FILHO, H. M. Eletroforese de proteinas. Rio de Janeiro: Richet Nouvelles, set. 2008. ano 11, n. 3, p. 1-8.

VANNUCCHI, H.; UNAMUNO, M. R. D. L.; MARCHINI, J. S. Avaliação do estado nutricional. Medicina, Ribeirão Preto, v. 29, n. 1, p. 5-18, jan./mar. 1996.

WATSON, T. D. G. Diet and skin deseases in dogs and cats. Journal of Nutrition: Nutrition and Desease, Houston, v. 128, n. 12, p. 2789S-2783S, 1998. 